\title{
Covalently-Linked Hyaluronan versus Acid Etched Titanium Dental Implants: A Crossover RCT in Humans
}

\author{
Saturnino Marco Lupi ${ }^{1, *} \mathbb{*}$, Arianna Rodriguez y Baena ${ }^{1}$, Clara Cassinelli ${ }^{2}$, Giorgio Iviglia ${ }^{2} \mathbb{D}$, \\ Marco Tallarico $\left.^{3}{ }^{(}\right)$, Marco Morra ${ }^{2}$ and Ruggero Rodriguez y Baena ${ }^{1}$ (i) \\ 1 Department of Clinico-Surgical, Diagnostic and Pediatric Sciences, Dental Clinic, University of Pavia, \\ P.le Golgi 2, 27100 Pavia, Italy; arianna_rodriguez@hotmail.it (A.R.yB.); \\ ruggero.rodriguez@unipv.it (R.R.yB.) \\ 2 Nobil Bio Ricerche srl, V. Valcastellana 26, 14037 Portacomaro, Italy; ccassinelli@nobilbio.it (C.C.); \\ giviglia@nobilbio.it (G.I.); mmorra@nobilbio.it (M.M.) \\ 3 Private Practice, V. Vincenzo Ussani 86, 00151 Roma, Italy; me@studiomarcotallarico.it \\ * Correspondence: saturninomarco.lupi@unipv.it; Tel.: +39-382-516-255
}

Received: 30 December 2018; Accepted: 6 February 2019; Published: 11 February 2019

\begin{abstract}
Biochemical modification of titanium surfaces (BMTiS) entails immobilization of biomolecules to implant surfaces in order to induce specific host responses. This crossover randomized clinical trial assesses clinical success and marginal bone resorption of dental implants bearing a surface molecular layer of covalently-linked hyaluronan in comparison with control implants up to 36 months after loading. Patients requiring bilateral implant rehabilitation received hyaluronan covered implants in one side of the mouth and traditional implants in the other side. Two months after the first surgery, a second surgery was undergone to uncover the screw and to place a healing abutment. After two weeks, the operator proceeded with prosthetic procedures. Implants were evaluated by periapical radiographs and the crestal bone level was recorded at mesial and distal sites-at baseline and up to 36 months. One hundred and six implants were positioned, 52 HY-coated, and 48 controls were followed up. No differences were observed in terms of insertion and stability, wound healing, implant success, and crestal bone resorption at any time considered. All interventions had an optimal healing, and no adverse events were recorded. This trial shows, for the first time, a successful use in humans of biochemical-modified implants in routine clinical practice and in healthy patients and tissues with satisfactory outcomes.
\end{abstract}

Keywords: dental implants; surface modification; hyaluronan; clinical trial

\section{Introduction}

Ever since the pioneering studies of Professor Brånemark, osseointegration of titanium implant fixtures has been recognized as an interfacial event [1]. The clinical practice of implant dentistry has been based on the intimate apposition of newly formed bone tissue to the titanium surface. A great deal of literature has been devoted to the relationship between titanium surface properties and new bone formation [2-4]. The primary physical-chemical variables, titanium oxide surface chemistry, and implant surface topography dictate relevant surface parameters-such as surface charge and wettability-and have been deeply investigated in relation to cellular events leading to peri-implant bone regeneration [5-11]. The understanding of such relationships prompted the clinical evolution of titanium implants from the original turned to present day micro- and nano-rough surfaces [12-14].

Parallel to the growth and widespread acceptance of dental implantology, rising knowledge framed relevant interfacial biological events within a broader picture [15-18]. Cellular mechanisms 
leading to new bone formation and soft tissue healing, as well as inflammatory response leading to loss of supporting soft and hard tissue, are mediated by biological molecules and relevant signaling. The presentation of biomolecular cues, rather than the comparatively rough inorganic chemistry of titanium, seems a reasonable highway towards the evolution of better and innovative implant surfaces [19]. Accordingly, surface engineering of medical devices has long since been involved with the immobilization of a wide range of biomolecules to medical materials surfaces $[20,21]$. Biochemical modification of titanium surfaces (BMTiS) was defined by Puleo and Nancy [22] as the immobilization of proteins, enzymes, or peptides with the purpose of inducing specific cell and tissue responses using critical organic components of bone to affect tissue response. BMTiS are generally based on surface modification either by peptides, ECM proteins, or polysaccharides, all from animal and vegetal sources [23-34]. Despite a huge number of studies and promising in vitro and pre-clinical results [35], no practical application exists so far, and clinical performances of present-day dental implants are still dictated by the titanium/host tissue interface and mostly based on stimulation of cell behavior by surface topography.

This work presents the results of the first clinical trial involving bio-molecular modification of titanium implant surfaces. Implant fixtures used in the present trial bear a surface nano-layer (a few $\mathrm{nm}$ thick) of covalently-linked hyaluronic acid or hyaluronan [while its common acronym is HA, it is indicated as $\mathrm{HY}$ in the present paper to avoid any risk of confusion with the widely used inorganic HA (hydroxyapatite)-coatings]. This means that they present a complex macromolecular chemistry and not the relatively simple inorganic chemistry of titanium surfaces at the implant/tissue interface.

HY (Figure 1) is a linear polysaccharide consisting of the repeating disaccharide unit $N$-acetyl-D-glucosamine-D-glucuronate linked by $\beta 1-4$ and $\beta 1-3$ linkages. It is involved with a huge number of cellular processes [36-39].

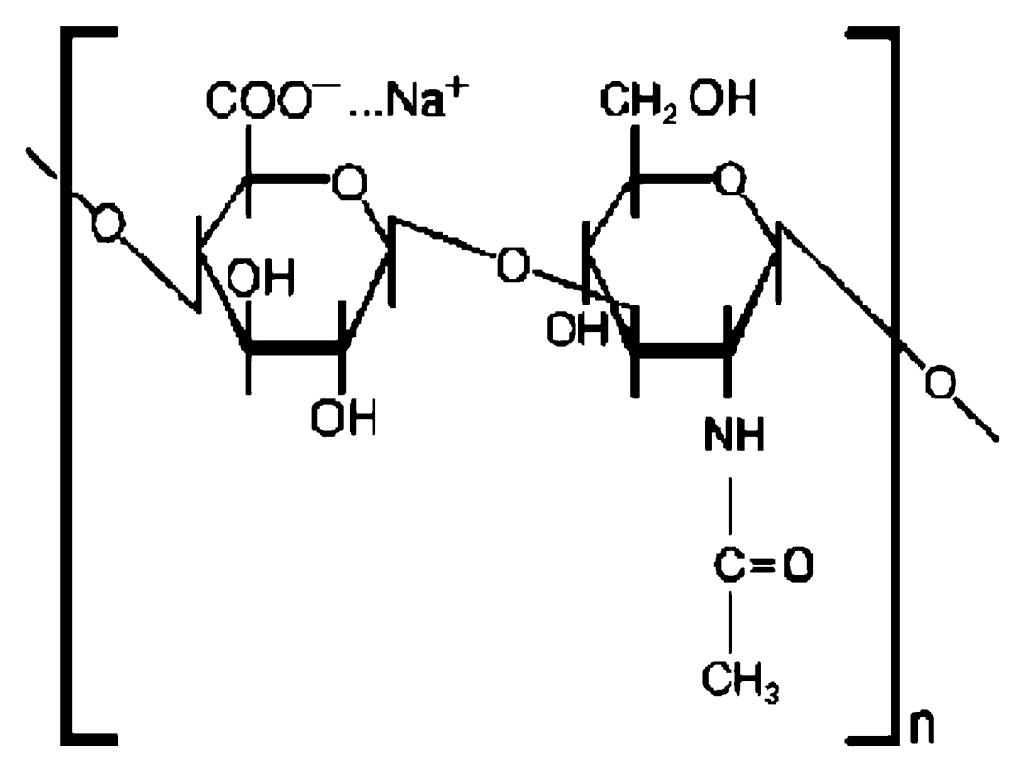

Figure 1. The repeating unit of Hyaluronan (HY).

Contrary to more complex glycosaminoglycans, $\mathrm{HY}$ is not sulfated, and it does not occur as part of a proteoglycan linked to a protein carrier. Significant interest in $\mathrm{HY}$ as a biomaterial and in biomaterials surface modification exists [40]. HY in medicine is mostly exploited because of its physical properties (hydration, viscosity, space filling), or by taking advantage of the hydration-promoted ability to reduce non-specific adhesion. Growing knowledge on $\mathrm{HY}$ as a key molecule in the regulation of many cellular processes involved with wound healing and tissue regeneration suggests that even more opportunities lie in the exploitation of its specific biological and bioactive properties [41-43]. 
Several literature reports indicate the potential interest of HY in BMTiS. Concerning bone regeneration, since the fifties it has been known that considerable HY is synthesized in the early stages of callus formation during the repair of fractured long bones [44]. Iwata and Urist [45] found that large amounts of HY were secreted when implants of decalcified bone underwent remineralization as bone. Bernard and coworkers presented studies aimed at developing "a foundation for the use of HY as a superior carrier for osteotropic substrates, even as HY acts to enhance osteogenesis due to its own molecular structure" [46]. Their in vitro studies using fetal calvarial cells and bone marrow osteogenic stem cells show that osteogenesis in vitro is significantly enhanced by HY 30-160 kDa, while high Mw HY (550-1300 kDa) shows weak inhibitory effects compared to the control. Zou and coworkers reported that $800 \mathrm{kDa}$ HY added to bone marrow stromal cells cultured in vitro accelerates cell proliferation, increases alkaline phosphatase activity and osteocalcin gene expression, and that HY interacts with BMP-2 to generate direct and specific cellular effects [47]. Ito and coworkers showed that locally applied $900 \mathrm{kDa}$ HY has a positive effect in bone ingrowth in Titanium fiber mesh implant in rats [48]. According to Cho, HY shows a positive effect in early bone consolidation in distraction osteogenesis [49]. HY based scaffolds aid in the regeneration of cartilage and bone defects in tissue engineering applications. The hypothesis of an active role played by local HY delivery upon scaffold degradation was suggested [50]. Zhao et al. [51] investigated the role of molecular weight and concentration of HY on the proliferation and osteogenic differentiation of rabbit bone marrow-derived stem cells in vitro. Factorial analysis indicated that molecular weight (MW) and concentration had an interactive effect on alkaline phosphatase mRNA expression $(p<0.05)$. HY of higher MW and higher concentration promoted bone formation. Regarding the in vivo studies on HY-coated implants, Aebli et al. [52] did not find bone growth increase in tests involving a sheep model. It should be noted that in the quoted study, the water-soluble HY was simply applied from solution to hydroxyapatite-coated implants without any intervening chemical bond to prevent rapid wash off [40]. An in vivo study on surface-engineered titanium implants bearing instead of a covalently-linked HY molecular surface layer in a four week rabbit model showed improvement of both bone to implant contact and bone ingrowth by hystomorphometry, while mechanical testing and evaluation of interfacial bone micro-hardness confirmed a faster bone maturation around HY coated implants [53]. Based on these and other encouraging pre-clinical results, the present study was conducted to investigate the clinical potential of HY covalently-linked implants and to set a starting point for future developments. The main goal was to confirm, in clinical practice and adopting objective clinical evaluation criteria, that "it is possible to do without the titanium surface chemistry". Once this point is set in routine clinics, pathways to actual exploitation of biomolecular signaling properties in compromised or challenging cases can be explored.

The paper presents first a detailed investigation of HY-coated titanium implants surfaces and relevant uncoated controls by SEM, energy dispersive X-ray spectroscopy (EDX), and X-ray photoelectron spectroscopy (XPS). Results of the clinical trial are then presented and discussed.

This split-mouth randomized clinical trial is aimed at assessing the clinical success and marginal bone resorption of dental implants bearing a surface molecular layer of covalently-linked hyaluronan in comparison with traditional sand-blasted and etched titanium implants up to 36 months after loading.

\section{Results}

\subsection{Scanning Electron Microscopy/EDX Analysis}

The surface topography of control and HY-coated implants was evaluated by SEM. Figures 2 and 3 show obtained results at $3000 \times$ and $10,000 \times$. 


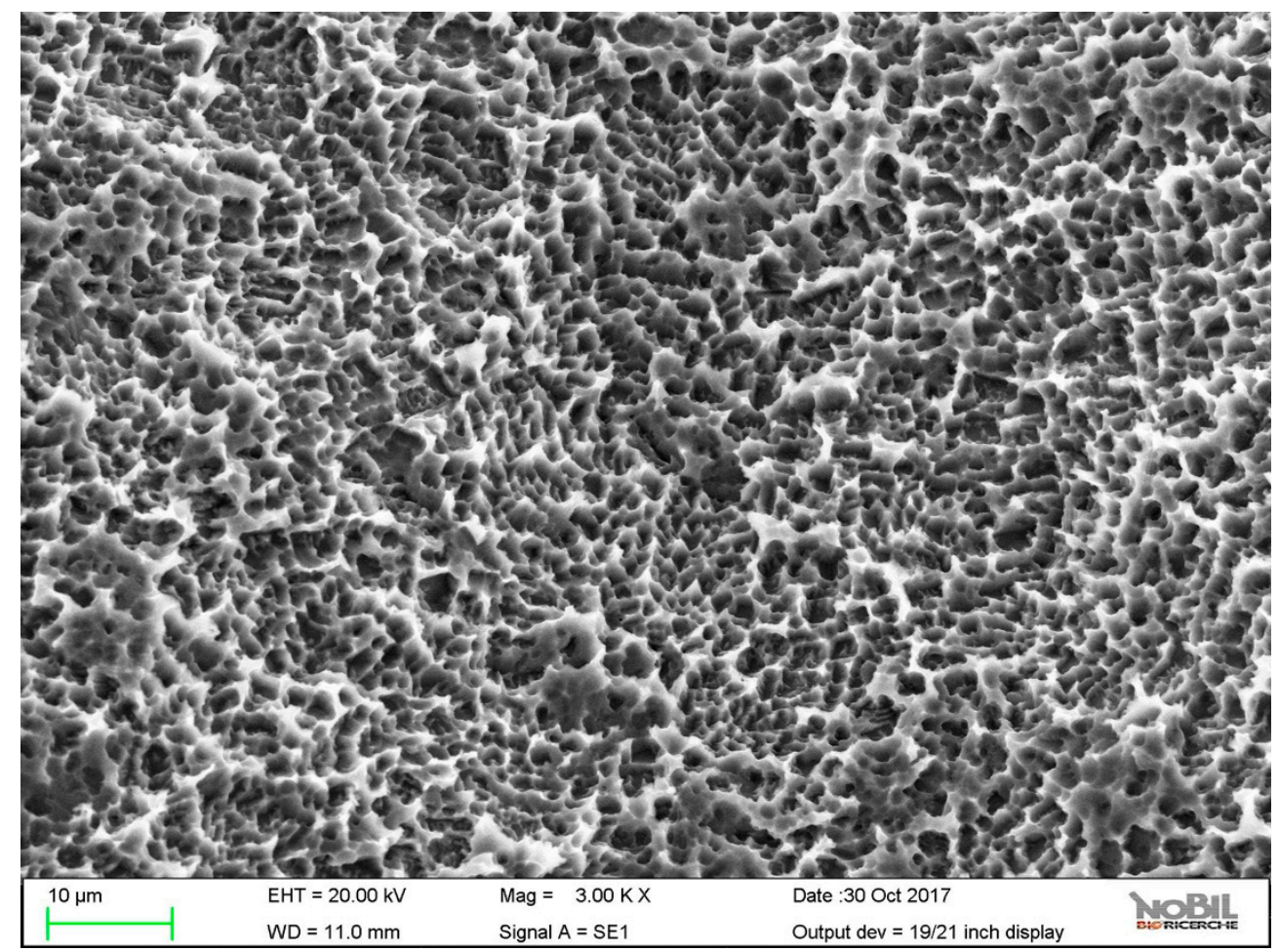

(a)

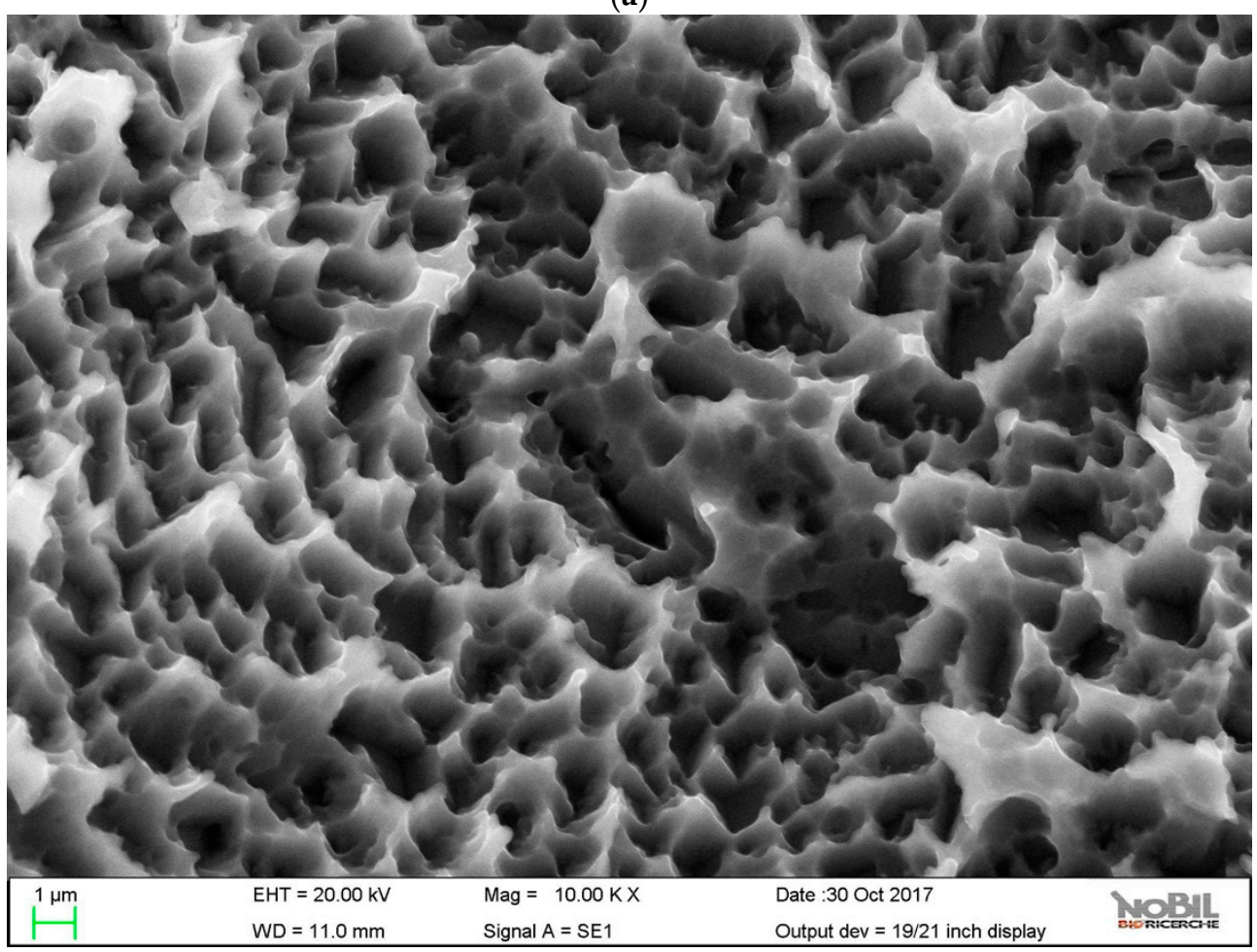

(b)

Figure 2. SEM images of the control implant surface, (a) 3000×; (b) 10,000×. 


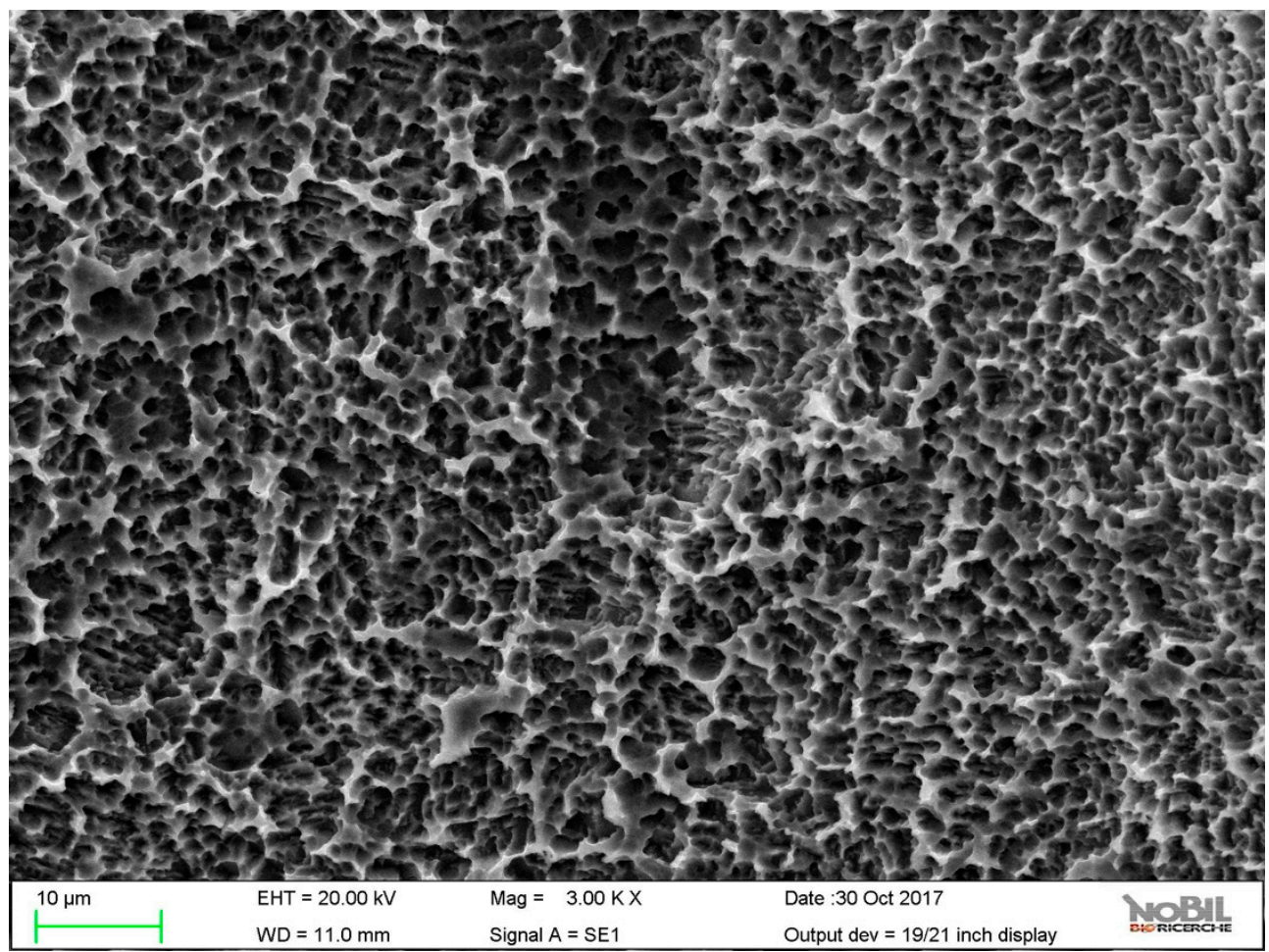

(a)

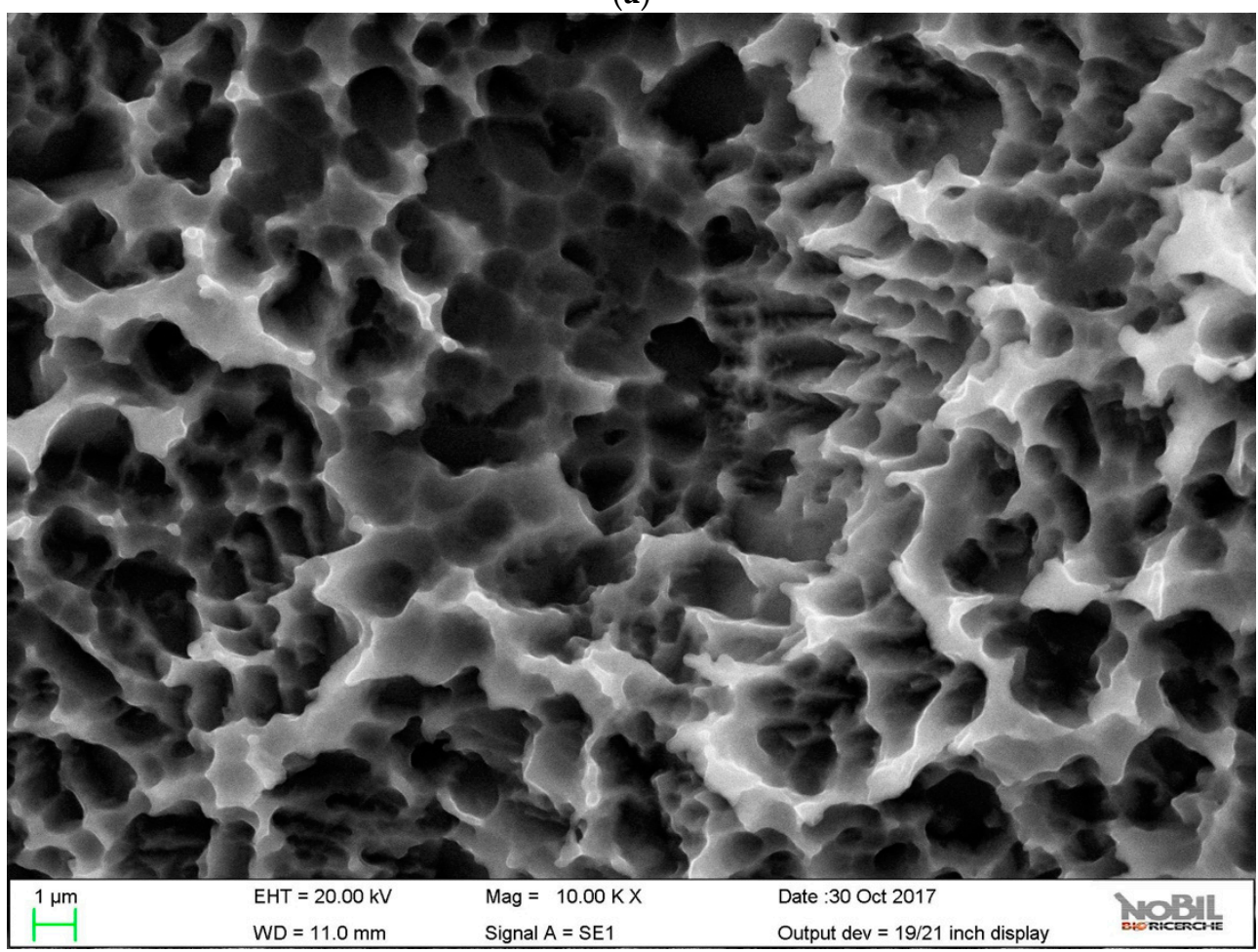

(b)

Figure 3. SEM images of the hyaluronan- (HY) coated implant surface, (a) $3000 \times$; (b) 10,000 $\times$.

Both samples showed the typical microtopography of doubly acid etched surfaces-a microrough surface where the distance between peaks was of the order of the micrometer. As reported in the literature, a peak distance lower than the typical cell length can stimulate cell behavior, thus promoting accelerated osteogenesis [54,55]. No evidence of the HY coating was observed, even at 10,000×. Surface linking of HY involved just molecular layers, whose thicknesses were approximately a few 
nanometers at most [40]. At this level of magnification, it was not detected over the microrough landscape provided by the doubly acid etched titanium surface. Table 1 reports the roughness parameters according to ISO 4287 that were obtained by the stereo-SEM reconstruction of the surface topography obtained from $2000 \times$ images, as described in the Materials section. A $900 \mu \mathrm{m}$ path length and an $80 \mu \mathrm{m}$ cut-off wavelength were used. No significant difference between samples was observed.

Table 1. Roughness parameters obtained by stereo-SEM. Data are expressed in $\mu \mathrm{m}$ as average and standard deviation of three measurements.

\begin{tabular}{cccccc}
\hline \multirow{2}{*}{ Parameter } & \multicolumn{2}{c}{ Control } & \multicolumn{2}{c}{ HY-Coated } & \multirow{2}{*}{ Description } \\
\cline { 2 - 5 } & Mean & Std & Mean & Std & \\
\hline $\mathrm{Ra}$ & 0.97 & 0.19 & 0.93 & 0.24 & Average roughness of profile \\
$\mathrm{Rq}$ & 1.26 & 0.29 & 1.23 & 0.34 & Root-Mean-Square roughness of profile \\
$\mathrm{Rt}$ & 7.96 & 0.77 & 6.87 & 1.13 & Maximum peak to valley height of roughness profile \\
$\mathrm{Rz}$ & 5.67 & 1.23 & 5.77 & 1.15 & Mean peak to valley height of roughness profile \\
$\mathrm{Rmax}$ & 7.93 & 0.75 & 6.41 & 0.99 & Maximum peak to valley height of roughness profile within a sampling length \\
$\mathrm{Rp}$ & 4.33 & 0.63 & 3.93 & 0.73 & Maximum peak height of roughness profile \\
$\mathrm{Rv}$ & 3.63 & 0.14 & 2.93 & 0.45 & Maximum valley height of roughness profile \\
$\mathrm{Rc}$ & 3.69 & 0.64 & 3.62 & 1.03 & Mean height of profile irregularities of roughness profile \\
$\mathrm{Rsm}$ & 43.22 & 9.69 & 53.77 & 19.90 & Mean spacing of profile irregularities of roughness profile \\
\hline
\end{tabular}

Figure 4 shows the energy dispersive X-ray spectroscopy (EDX) spectra obtained from the two samples. Both of them showed a very strong signal from titanium. In the case of the HY-coated implant, small but significant peaks due to carbon and oxygen were detected as well, suggesting the presence of an organic surface layer.

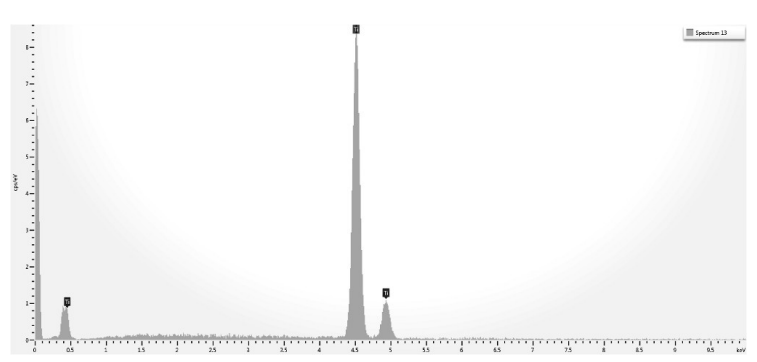

(a)

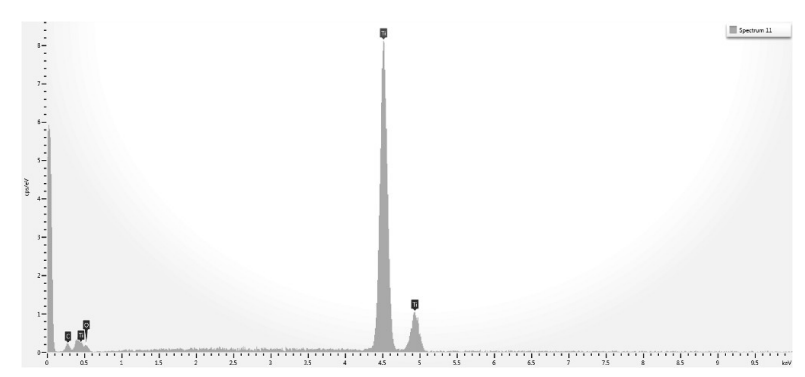

(b)

Figure 4. EDX spectra of control (a) and HY-coated (b) titanium implant.

\subsection{X-Ray Photoelectron Spectroscopy}

XPS wide-scan spectra of control and HY-coated dental implants used in the present clinical trial are shown in Figure 5.

The control implant showed the typical composition of titanium surfaces, yielding signals due to photoemitted electrons from core levels of the expected elements: titanium, oxygen (because of the native titanium oxide surface layer), and carbon (due to surface adsorption of ubiquitous carbon-containing compounds from the atmosphere and nitrogen). The overall surface composition, reported in Table 2, was in good quantitative agreement with data from the literature. It showed no unexpected elements or contamination, and its $\mathrm{C} / \mathrm{Ti}$ ratio was indicative of excellent surface cleanliness $[7,56]$. 


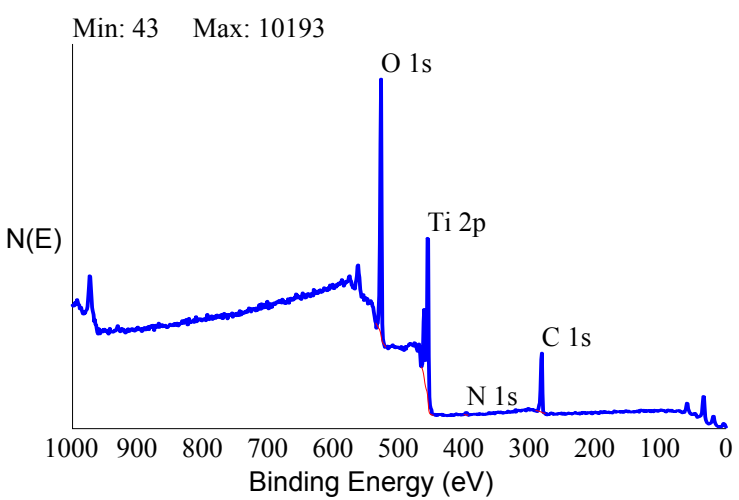

(a)

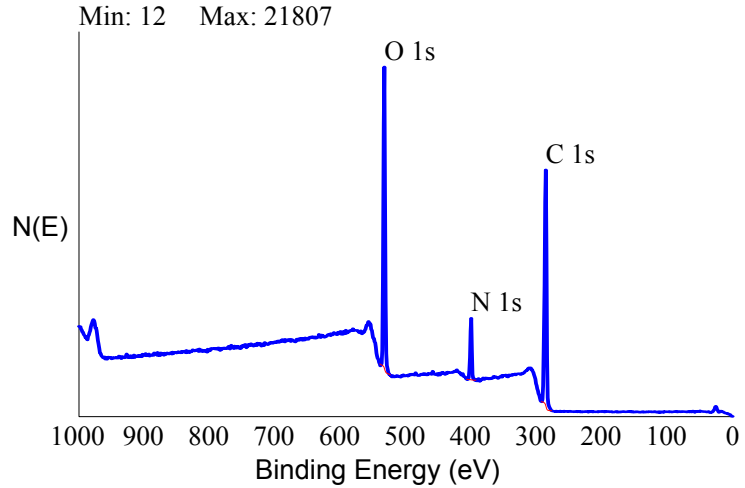

(b)

Figure 5. X-ray photoelectron spectroscopy (XPS) wide-scan spectra of control (a) and HY-coated (b) titanium implant.

Table 2. Surface composition (\% at.) of Control and HY-coated implants.

\begin{tabular}{ccccc}
\hline Sample & $\mathbf{O}$ & $\mathbf{T i}$ & $\mathbf{N}$ & $\mathbf{C}$ \\
\hline Control & 51.4 & 17.1 & 1.0 & 30.5 \\
HY-coated & 28.7 & - & 7.9 & 63.4 \\
\hline
\end{tabular}

The XPS spectrum of the HY-coated implant, on the other hand, showed a completely different picture. First and foremost, there was no signal from titanium at all. The only elements detected in the nanometer-thick sampling depth probed by XPS were the basic elements of organic chemistry-oxygen, carbon, and nitrogen. The elemental ratio reported in Table 2 was consistent with typical polysaccharides stoichiometry, showing a high $\mathrm{O} / \mathrm{C}$ ratio. Perusal of the literature confirmed that the detected surface stoichiometry was consistent with the reported composition of covalently-linked HY through aminated spacers [57]. Further clues were offered by the sensitivity to the carbon chemical environment provided by the high-resolution peak of $\mathrm{C} 1$ s photoelectrons. Figure 6 shows $\mathrm{C} 1 \mathrm{~s}$ peaks of the tested control and HY-coated dental implants.

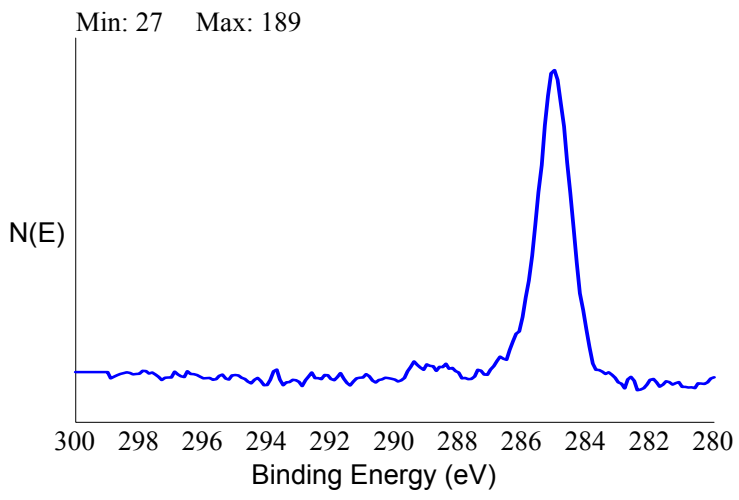

(a)

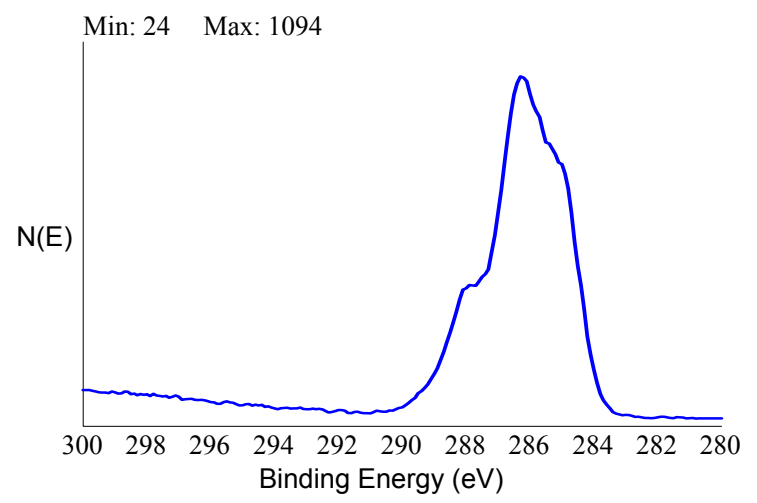

(b)

Figure 6. XPS high-resolution C1s peak of control (a) and HY-coated (b) titanium implant.

In the former case, the peak was relatively simple and symmetrical, confirming that it was mostly due to $\mathrm{C}-\mathrm{C}$ and $\mathrm{C}-\mathrm{H}$ functionalities from adventitious hydrocarbons. The $\mathrm{C} 1$ s peak of the HY-coated implant was much broader and clearly contained different components. De-convolution of the C1s peak of the HY-coated implant following general XPS practice [58] is shown in Figure 7. 


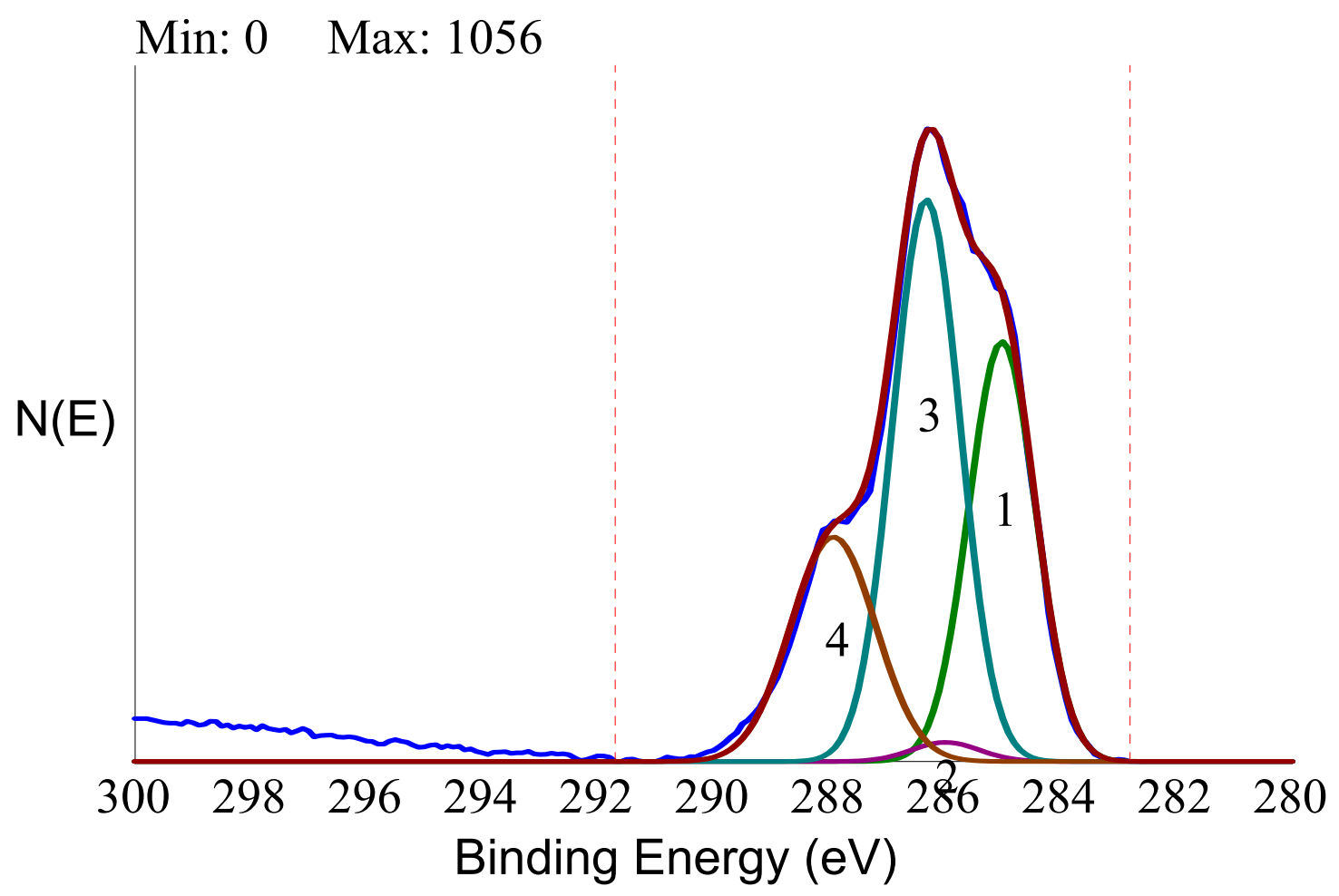

Figure 7. Curve fitting of high-resolution C1s peak of the HY-coated titanium implant by the four components expected from the molecular structure of hyaluronan.

The experimental curve was fitted according to literature indication [59] by four components located at $285.00 \mathrm{eV}(\mathrm{C}-\mathrm{C}, \mathrm{C}-\mathrm{H}), 286.15 \mathrm{eV}(\mathrm{C}-\mathrm{N}), 286.50 \mathrm{eV}(\mathrm{C}-\mathrm{O})$, and $288.10 \mathrm{eV}(\mathrm{C}=\mathrm{O}, \mathrm{N}-\mathrm{C}=\mathrm{O}$, and $\mathrm{O}-\mathrm{C}=\mathrm{O}$ functionalities). Peak de-convolution showed that the carbon chemical environment at the HY-coated titanium implant surface was dominated by the carbon single bond oxygen functionality typical of polysaccharides, and that the experimental C1s peak contained all features expected from the molecular structure of HY. Taken together, these data convincingly showed that the outermost nanometers of the HY-coated implant surface presented to the external environment the molecular cues stemming from the HY repeating unit, which was a completely different chemical nature when compared to the titanium oxide surface of the conventional control implant.

\subsection{Clinical Trial}

From 8 April 2013 to 17 October 2014, 106 implants were positioned in 30 patients (demographic data in Table 3).

Table 3. Demographic data and implant location. Data in absolute values and (\%).

\begin{tabular}{cccc}
\hline Demographic Data & Total & HY & C \\
\hline Males & $21(70)$ & & \\
Females & $9(30)$ & & \\
Patients mean age & $59.8 \pm 10.6$ & & \\
\hline Implant location & & & \\
\hline Anterior maxilla & $18(17.0)$ & $9(16.4)$ & $9(17.6)$ \\
Posterior maxilla & $41(38.7)$ & $24(43.6)$ & $17(33.3)$ \\
Anterior mandibula & $10(9.4)$ & $5(9.0)$ & $5(9.8)$ \\
Posterior mandibula & $37(34.9)$ & $17(30.9)$ & $20(39.2)$ \\
\hline
\end{tabular}


During surgery, no differences were observed in regards to the insertion and stability between the two types of implants (test and control), nor were differences observed in the post-operative visits in regards to the indices of inflammation and wound healing. The healing was uneventful in all of the patients in the variability of the surgical situation, and no adverse events whatsoever were recorded. Only 102 implants in 29 subjects out of the 106 implanted were loaded and taken as baselines for X-ray values (mesial and distal). Two implants (one control and one HY coated) in two different patients failed and were removed. In both cases, the mucosa appeared edematous and bleeding, indicating signs of an infection. In one case, the implant was not replaced, and since no matching controls were available, the subject (Subject $\mathrm{N}^{\circ} 34$ ) was excluded from the efficacy analysis. In the second subject, the failed implant was relocated in the same place after two months, reaching healing and tissue stabilization. Therefore, the subject was maintained in the statistics. One subject with two implants (one control and one HA) dropped out between the 12 months and the 18 months follow up visits due to a desire for pregnancy and therefore the unethical use of $\mathrm{X}$-ray procedures. Results are summarized in Table 4.

Table 4. Bone resorption.

\begin{tabular}{|c|c|c|c|c|c|c|c|}
\hline \multirow{2}{*}{ Time Points } & \multicolumn{2}{|r|}{ HY } & \multicolumn{2}{|r|}{$\mathrm{C}$} & \multirow{2}{*}{$\begin{array}{c}p \\
\text { (between-Group) }\end{array}$} & \multicolumn{2}{|c|}{ 95\% Confidence Interva } \\
\hline & $n$ & Mean \pm sd & $n$ & Mean \pm sd & & Min & Max \\
\hline \multicolumn{8}{|l|}{ Mesial } \\
\hline 3 & 51 & $0.55 \pm 0.46$ & 47 & $0.51 \pm 0.65$ & 0.64 & -0.24 & 0.55 \\
\hline 6 & 24 & $0.72 \pm 0.38$ & 20 & $0.65 \pm 0.39$ & 0.58 & -0.30 & 0.17 \\
\hline 12 & 35 & $0.83 \pm 0.61$ & 35 & $0.66 \pm 0.58$ & 0.25 & -0.45 & 0.12 \\
\hline 18 & 16 & $0.65 \pm 0.63$ & 17 & $0.36 \pm 0.43$ & 0.14 & -0.67 & 0.10 \\
\hline 24 & 34 & $0.80 \pm 0.87$ & 32 & $0.50 \pm 0.57$ & 0.10 & -0.66 & 0.06 \\
\hline 36 & 21 & $0.55 \pm 0.40$ & 19 & $0.32 \pm 0.36$ & 0.06 & -0.47 & 0.01 \\
\hline \multicolumn{8}{|l|}{ Distal } \\
\hline 3 & 51 & $0.71 \pm 0.60$ & 47 & $0.70 \pm 0.62$ & 0.97 & -0.25 & 0.24 \\
\hline 6 & 24 & $0.77 \pm 0.60$ & 20 & $0.93 \pm 0.46$ & 0.30 & -0.15 & 0.49 \\
\hline 12 & 35 & $0.83 \pm 0.63$ & 35 & $0.85 \pm 0.60$ & 0.90 & -0.28 & 0.31 \\
\hline 18 & 16 & $0.72 \pm 0.53$ & 17 & $0.47 \pm 0.45$ & 0.16 & -0.59 & 0.11 \\
\hline 24 & 34 & $0.76 \pm 0.42$ & 32 & $0.63 \pm 0.62$ & 0.33 & -0.39 & 0.14 \\
\hline 36 & 21 & $0.62 \pm 0.53$ & 19 & $0.55 \pm 0.62$ & 0.70 & -0.44 & 0.30 \\
\hline
\end{tabular}

Time points: months; $n$ : number of implants; mean \pm standard deviation (sd) expressed in $\mathrm{mm}$.

The non-inferiority analysis did not show any significant differences between the HY- and the control- in terms of mesial and distal bone resorption at any time point.

\section{Discussion}

In the present clinical trial, a widely adopted microrough titanium surface and the same surface further modified by a covalently-linked nanolayer of hyaluronan were compared in terms of clinical success in routine clinical practice.

Analytical data confirmed the exquisitely superficial nature of the surface modification process that was adopted. The analytical signal captured in EDX analysis stemmed from a surface volume that was a few micrometers deep [60]. Thus, within the EDX sampling depth, the signal by the nanometers-thick HY surface layer was diluted within the micrometer-thick analytical layer, and the resulting spectrum contained convoluted contributions from the underlying Ti implant and the overlying HY molecules in roughly a 1000:1 ratio. As a consequence, the elements composing the surface layer were barely detectable. For this reason, a more surface-sensitive analytical technique, namely XPS, was conducted to fully appreciate the biomolecular modification of the HY-coated implants. Contrary to EDX analysis, the physics of photoelectrons escaped from solids endowed XPS with just a few nanometers of sampling depth, consequently providing chemical information on the 
outermost atomic layers of materials [58]. For this reason, XPS was extensively used in the surface analysis of dental implants [7,61-63].

Despite the widely different surface chemistry, objective optimal healing was observed for both groups, and no differences were detected in the clinical outcome for all tested parameters. Far from being uneventful, the described results suggested some important reflections. From a chemical-physical point of view, it would be difficult to imagine two more different surface structures-the titanium surface (in particular, the outermost few nanometers of oxidized titanium) presented a hard, impervious interface to the host tissue, whose chemical behavior was controlled by titanium oxide interfacial chemistry, as widely described in many scientific papers $[7,8,61]$. On the contrary, the HY-coated implant aqueous interface was diffuse, soft, and hydrated [64]. Its chemistry stemmed from the molecular details of the $\mathrm{N}$-acetyl-D-glucosamine-D-glucuronate repeating unit. Shortly, one of them (the control arm) belonged to inorganic chemistry. The HY-coated surface belonged instead to organic biomacromolecular chemistry. Despite being two worlds apart, no significant difference was detected in the tested clinical variables, and both of them led to successful osseointegration and clinical success. The first significant reflection from the data of the present work is that the titanium surface chemistry is not necessary to achieve a clinically satisfactory load-bearing capacity by a titanium dental implant.

The previous point could be interpreted as a no-effect of surface chemistry on osseointegration. As long as the implant surface is inert and no disturbance is introduced in the bone healing mechanism - that is, as long as no toxic or irritating compounds are released in the evolving new bone matrix independent from specific details of surface chemistry-clinically effective osseointegration will occur. If this is the case, no advancement is expected by BMTiS over conventional surfaces, and the sole opportunity to direct tissue response is through surface topography.

The last sentence falls short when compared to existing scientific evidence gathered from animal data, which shows direct effects of interfacial chemistry on bone healing in terms of peri-implant bone volume, bone to implant contact, or gene expression by peri-implant bone cells $[35,53,65,66]$. In the present clinical trial, a patient's selection and surgery addressed comparatively routine clinical practice. The control arm, involving a state-of-the-art doubly acid etched microrough surface, obviously provided optimal healing and clinical success. Endpoint variables aimed at general clinical evidence expectedly confirmed that both the well-known titanium interfacial chemistry and the biologically relevant HY molecular cued direct cellular events involved with peri-implant tissue healing towards proper clinical response.

HY is a key molecule in many tissue regeneration processes; it is involved with most of the mammalian cells' healing mechanisms [67-69] in a concentration and size-dependent way. The permanent linking of HY to materials surfaces avoids quick wash-off of the water soluble HY and aims at providing these regenerative properties at the peri-implant interface, as confirmed by several in vivo evidences. It is not clear yet how surface-immobilized HY compares with HY in solution in terms of the effect of the hindered conformational freedom on the multiple ligand-receptor interactions required to trigger a biological response [40]. It would be of interest to check the stimulation of bone tissue regeneration at machined interfaces of hybrid implants, the effect on soft tissue healing in the transmucosal section of tissue level implants, or the control of inflammatory responses of periodontal patients [70] and relevant clinical implications. The positive evidence supplied by the present clinical trial in standard practice opens the path to comprehensive investigation of the merits of BMTiS in clinical implantology by further finely-targeted clinical trials.

A last observation involves the relationship of present results with in vitro investigation of dental implant surfaces. A widely adopted approach involves the "adhesion and growth" paradigm, meaning that prospective surface structures are screened in terms of effects on adhesion and growth of osteoblast cells-the faster and more extensive the surface colonization by cells, the better the properties. Against this view, HY-coated surfaces are notoriously anti-adhesive in vitro [64,71], meaning that they prevent cell adhesion of a number of cell lines, including osteoblasts. Several applications of HY-coated 
surfaces are based on tissue-anti-adhesive properties. In vitro tests of present clinically successful HY-coated implants would provide unsatisfactory results if judged according to the "adhesion and growth" paradigm. Yet, clinical evidence as supplied by the present trial indicates that they are fit for the intended use. Far from being inconsistent, this evidence simply indicates the complexity of the peri-implant environment as opposed to the comparatively simple biological environment of in vitro tests. In clinics, osteoblasts do not adhere and grow onto the implant surface. Rather, they come to a complex peri-implant milieu after the blood clot and relevant blood cells, inflammatory cells, and the sequela of cytokine and growth factors are released in the initial stage of inflammation and healing [72]. Rather than the direct effect of the interfacial HY (or of any surface-linked biomolecular layer) on osteoblasts, it is the effect of molecular signaling on the evolution of the peri-implant biochemical environment that directs clinical outcome and that holds the potential merits of BMTiS in clinics.

In summary, the clinical trial did not record any significant difference between the HY- and the C-group in terms of clinical success and marginal bone resorption. In the present study, for the first time in clinics (to the author's knowledge), dental implants with a biomolecular nanolayer on the surface showed a behavior similar to the commercial pure titanium one. This study presents the limits to having a follow up limited to 36 months. The duration of the follow up was chosen because in this span of time, the HY layer should be completely integrated within the newly formed interfacial tissue. Further studies should be conducted to evaluate the long-term success of HY-implants. Present data build up the ethical basis for the investigation into the merits of HY-coated implants in more challenging and compromised cases where signaling and regenerative properties encoded within the HY molecular structure could play a role that is presently not supplied by the comparatively rough titanium surface chemistry.

\section{Materials and Methods}

\subsection{Titanium Implant}

The fixture used in the clinical trial was a CE marked titanium grade 4, internal hexagon, doubly acid etched implant (Ornaghi Luigi \& C, Brugherio, Italy). The implant fixture was further coated by covalently-linked HY by Nobil Bio Ricerche (Nobil Bio Ricerche srl, Portacomaro, Italy) through a proprietary process, as described in the Results section. Covalent-linking prevented the rapid wash-off of the water-soluble HY molecules, degradation by hyaluronidase, and release. The thickness of the coating, as discussed in the following sections, was a few nanometers and did not modify the nominal dimensions. The control was the same implant not coated with covalently-linked HY.

\subsection{Surface Characterization}

\subsubsection{Scanning Electron Microscopy}

The surface topography of the implants was evaluated by SEM. Analysis was conducted using an EVO MA 10 SEM (Carl Zeiss Microscopy GmbH, Jena, Germany). The electron acceleration voltage was maintained at $20 \mathrm{kV}$ with the working distance between 10 and $12.5 \mathrm{~mm}$. These parameters are reported in the images, along with level of magnification (MAG) and the kind of detector utilized (Signal A = SE1 or CZ BSD).

Images were acquired in both conventional mode (Signal A = SE1) and in backscattered electron mode (Signal A = CZ BSD), allowing improved contrast between different chemical elements.

Roughness was evaluated quantitatively by stereo-SEM (SSEM) using dedicated software to convert conventional SEM images into three-dimensional data (Mex 6.0, Alicona Imaging, Raaba/Graz, Austria). A stereo-pair was built by the acquisition of the same field of view at zero and after five degrees of eccentric tilting. Following the principles of stereoscopic vision, the stereo pair was transformed into a three-dimensional reconstruction of the surface by the quoted software, providing height profiles values used as input data for the calculation of roughness parameters 
according to ISO 4287 . The stereo-pairs were built from $2000 \times$ images taken from three randomly selected areas for each implant.

\subsubsection{X-ray Photoelectron Spectroscopy (XPS)}

XPS analysis was performed using a Perkin Elmer PHI 5600 ESCA system (PerkinElmer Inc., Waltham, MA, USA). The instrument was equipped with a monochromatized $\mathrm{Al}$ anode operating at $10 \mathrm{kV}$ and $200 \mathrm{~W}$. The diameter of the analyzed spot was approximately 500 micrometers, and the analyzed depth was about 5 nanometers. The base pressure was maintained at $10-8 \mathrm{~Pa}$. The angle between the electron analyzer and the sample surface was $45^{\circ}$. Analysis was performed by acquiring a wide-range survey spectra (0-1000 eV binding energy) and detailed high-resolution peaks of relevant elements. Quantification of elements was accomplished using the software and sensitivity factors supplied by the manufacturer. High-resolution C1s peaks were acquired using pass energy of $11.75 \mathrm{eV}$ and a resolution of $0.100 \mathrm{eV} / \mathrm{step}$.

\subsection{Clinical Trial}

The study "Blind Comparison of Covalently-Linked Hyaluronan versus Control-Dental Implants in a Randomized Crossover Clinical Investigation" is a post market clinical follow-up according to MEDDEV 2.12-2 rev 2 January 2012 conducted at the Dental Service, Department of Clinical, Surgical, Diagnostic, and Pediatric Sciences, University of Pavia, Pavia, Italy. The clinical trial was conducted according to the ISO 14155-11 and the Good Clinical Practice Guidelines (GCP). The study was carried out following the rules of the Declaration of Helsinki, as revised in 2013 and approved by the Ethical Committee of the University of Pavia on 13 December 2012. On 28 February 2013, the initiation of the study was communicated to the Italian Ministry of Health with the reference number 000017. All subjects gave their informed consent for inclusion before they participated in the study. The primary objective of this non-inferiority, crossover, fixed-size, and single-center trial was to assess the dental implant success (survival rate) of HA coating implants in comparison with control implants at one year. The secondary objective was to assess marginal bone resorption of HA coating implants in respect to traditional titanium implants measured at 3, 6, 12, 18, 24, and 36 months. To test the non-inferiority hypothesis of the HY-coated implant in respect to control implants, the null hypothesis was that the HY-coated implant resulted in a lower survival rate and a higher marginal bone loss in respect to the control implant. The P level of significance was set at 0.05 . Patients with bilateral partial or full edentulism requiring implant rehabilitation were enrolled; inclusion and exclusion criteria are shown in Tables 5 and 6.

Table 5. Criteria for inclusion in the clinical trial.

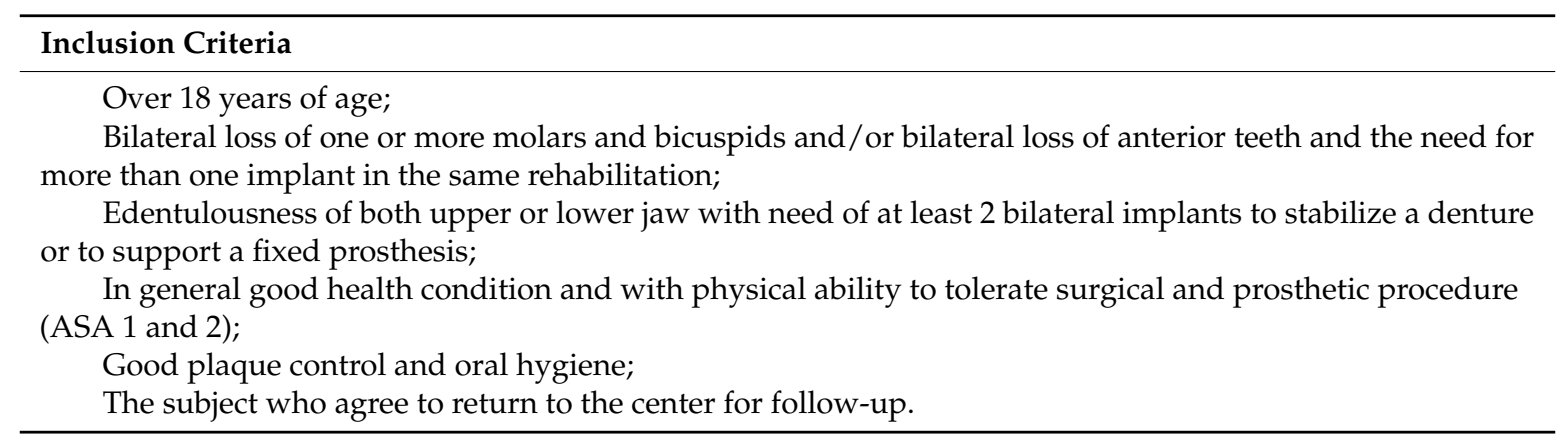


Table 6. Criteria for exclusion from the clinical trial.

\section{Exclusion Criteria}

Active infection or severe inflammation or suspected lesions in the areas intended for implant installation; Diabetes (regardless of control);

Need for concomitant bone grafting and/or having less than $1 \mathrm{~mm}$ bone available at the buccal, lingual, and apical aspects of the implant. Less than $3 \mathrm{~mm}$ distance between implant and other dentition;

Under treatment and/or within the past 12 months with radiotherapy to the head or chemotherapy;

Suspected hypersensitivity and/or contraindication to any ingredients of the Investigational Device

(ID)/Control ID;

Subjects under any study medication treatment in the last 30 days;

Pregnancy, breast feeding, oocyte donation, or oocyte implantation planned during the study;

Subjects not able to follow study procedures, e.g., language problems, psychological disorders;

Clinically relevant abnormal laboratory values suggesting an unknown disease and requiring further clinical evaluation (as assessed by the investigators);

Female subjects of childbearing potential, not using and not willing to continue using a medically reliable method of contraception for the entire study duration;

Any other untoward medical condition that could interfere with the participation of the subject in the trial.

In this study, concealment and randomization were implemented centrally by an operator (G.O.) unrelated to the surgical team, to the clinical examiner, and to the statistician. After manufacturing, implants were packaged in consecutively numbered boxes. Each box contained six implants, three with the HY surface (marked with A or B) and three with the control surface (marked with B if the HY implants were marked with A, or marked with A on the contrary). All of the implants were $4 \mathrm{~mm}$ in diameter and were 8,10 , and $12 \mathrm{~mm}$ long. The two surfaces were macroscopically indistinguishable. The assignation of the label (A or B) to the surfaces was randomly assigned in each box by a computer random number generator. Data were communicated to the statistician, omitting the surface characteristic. The list of randomization was concealed until after statistical analysis was concluded. Due to the split-mouth design of the study and the randomization process, the allocation ratio was 1:1. No block restrictions were applied.

\subsubsection{Surgical Procedure}

During surgery, implant(s) with one surface were placed in one side of the mouth and implant(s) with the other surface were placed in the other side of the mouth. When a patient required placement of the number of implants equal in both sides of the mouth, each couple of implants came out from a different box. When the number of implants required in one side of the mouth was greater than the other side, implants were chosen among those available in the opened boxes. If the odd implants were not available in the opened boxes, no experimental implants were positioned. This procedure was implemented after protocol approval because the surgical team signaled the problem of re-operating in patients with a different number of edentulous sites in the two sides of the mouth. Even though it was not necessary because randomization was implemented before surgery, the implant label choice for the sides of the mouth was randomized by a coin toss. The surgical protocol of installing the implants was well documented and consisted of a full thickness mucosal flap elevation, the preparation of the implant site, the installation of the implant with the prosthetic platform (that is, the edge of the collar) at the level of the bone crest, the positioning of the surgical cover screw, and the closing of the flap with sutures [73-80]. The surgery was done under coverage of antibiotics ( $2 \mathrm{~g}$ of amoxicillin and clavulanic acid per os one hour before surgery, followed by administration of $1 \mathrm{~g}$ after 6 and $18 \mathrm{~h}$ ). The post-operative instructions indicated rinses with chlorhexidine $0.12 \% \times$ three times a day from the day after surgery and for 30 days and control of the pain with anti-inflammatory drugs as needed. The removal of the sutures was carried out from the tenth to the fourteenth day.

The second stage of surgery was conducted after two months, both in the mandibular and in the maxillary arch. After about two weeks, the operator proceeded with the prosthesis installation. During follow-up visits, normal hygienic procedures were carried out when needed [81]. 


\subsubsection{Investigation Hypothesis or Pass/Fall Criteria}

The primary objective of the present study was to assess the success of HY coated implants in comparison with control implants after one year. The implant is considered successful (primary endpoints) if: (A) the implant is still present without any sign of mobility and (B) there is no evidence of radiolucency by means of periapical X-rays and (C) there is no clinical sign of peri-implantitis. The secondary objective of the present study was to demonstrate a non-inferiority of the HY-coated implants compared to the control implants considering the marginal bone resorption parameter. To do this, the null hypothesis is that control implants demonstrate an inferior crestal bone resorption in respect to HY coated implants.

\section{Sample Size Calculation}

The sample size was estimated based on the crestal bone level at 12 months post implant.

Since the objective of this study was the non-inferiority of the investigational device (ID) compared to the Control ID in a crossover design from data published by Mumcu [82], inferior limits for the Control ID were estimated.

Practically, from pooling data reported in Table 1 of Mumcu and Coll., an inferior limit of $0.7 \mathrm{~mm}$ was estimated and considered clinically appropriate. This implies that if the lower bond of the $95 \%$ confidence interval for the estimated difference in crestal bone level between implants is above $-0.7 \mathrm{~mm}$, then the ID is considered non-inferior to the Control ID.

Sample size was calculated under the following assumptions:

- Lower limits in difference between implants: $-0.70 \mathrm{~mm}(\Delta)$

- Hypothesis testing:

- H0: $\mu$ Control ID- $\mu \mathrm{ID} \leq \Delta$

- H1: $\mu$ Control ID- $\mu$ ID $>\Delta$ (ID implant is non-inferior with respect to the mean response)

- $\alpha$ level of probability: 0.025 for one-sided test

- $\quad 1-\beta$ (power) level: $90 \%$ for a conservative approach

- Standard deviation for mean difference: 0.66 , which corresponded to $80 \%$ of the pooled mean calculated from Mumcu $(0.83 \mathrm{~mm})$. In this estimate, it was considered that the ID presented on the crestal bone level a greater variability in respect to the Control ID and that reported in the publication.

By applying the formula reported in Julius [83] for non-inferiority trials in crossover design:

$$
n=\frac{2 \sigma^{2}\left(Z_{(1-\beta)}+Z_{(1-\alpha)}\right)^{2}}{\left(\left(\mu_{\text {Control ID }}-\mu_{I D}\right)-d\right)^{2}}
$$

18 evaluable subjects are needed to demonstrate the non-inferiority of the ID in respect to the Control ID. Considering that a couple of devices are implanted into each subject, we need to have at least 18 implant pairs in order to reach the trial primary objective.

\section{Conclusions}

The clinical trial "Blind Comparison of Covalently-Linked Hyaluronan versus Control-Dental Implants in a Randomized Crossover Clinical Investigation" evaluated clinical success up to 36 months with HY-coated dental implants compared to the control-uncoated microrough Ti grade 4 implants. Results showed a lack of differences between the two arms of the study. Both of them provided optimal healing.

Substitution of the clinically accepted and consolidated titanium surface chemistry with the molecular structure of $\mathrm{HY}$ and ensuing interfacial interactions results in a satisfactory clinical outcome. 
Author Contributions: Conceptualization: S.M.L., A.R.yB., C.C., G.I., M.T., M.M. and R.R.yB.; methodology: S.M.L., C.C., M.M. and R.R.yB.; validation: A.R.yB., G.I., M.T. and R.R.yB.; formal analysis, S.M.L., C.C., M.M. and R.R.yB.; investigation, A.R.yB., G.I., M.T. and R.R.yB.; resources, A.R.yB.; data curation, S.M.L., M.M. and R.R.yB.; writing—original draft preparation, S.M.L. and M.M.; writing-review and editing, S.M.L., A.R.yB., C.C., G.I., M.T., M.M. and R.R.yB.; supervision, R.R.yB.; project administration, M.M.; funding acquisition, C.C., M.M. and R.R.yB.

Funding: The study was supported by Nobil Bio Ricerche srl, the profit company that executes the surface treatment process.

Acknowledgments: The authors thank: BSDpharma srl, under the responsibility of Claudio F. Omini, for the role in CRO duties and for monitoring of the study; Gabriele Omini for randomization list and labels and for monitoring of the study; Guido Fedele for statistical support; Giuseppe Zuccari for Quality Assurance; AA Gandolfi for monitoring of the study.

Conflicts of Interest: Marco Morra and Clara Cassinelli own shares of the funding company Nobil Bio Ricerche srl. Giorgio Iviglia is an employee of Nobil Bio Ricerche srl. Saturnino Marco Lupi, Arianna Rodriguez y Baena and Ruggero Rodriguez y Baena declare no conflict of interest.

\section{Abbreviations}

$\begin{array}{ll}\text { BMTiS } & \text { Biochemical modification of titanium surfaces } \\ \text { ECM } & \text { Extra Cellular Matrix } \\ \text { EDX } & \text { Energy Dispersive X-ray Analysis } \\ \text { GCP } & \text { Good Clinical Practice } \\ \text { HY } & \text { hyaluronic acid or hyaluronan } \\ \text { ID } & \text { Investigational Device } \\ \text { MAG } & \text { level of magnification } \\ \text { RCT } & \text { Randomized Clinical Trial } \\ \text { SEM } & \text { Scanning Electron Microscopy } \\ \text { XPS } & \text { X-ray Photoelectron Spectroscopy }\end{array}$

\section{References}

1. Branemark, P.I. Osseointegration and its experimental background. J. Prosthet. Dent. 1983, 50, $399-410$. [CrossRef]

2. Brunette, D.M.; Tengvall, P.; Textor, M.; Thomsen, P. Titanium in Medicine: Material Science, Surface Science, Engineering, Biological Responses and Medical Applications; Springer: Berlin, Germany, 2001.

3. Davies, J.E. The Bone-Biomaterial Interface; University of Toronto Press: Toronto, ON, Canada, 1991.

4. Ellingsen, J.E.; Lyngstadaas, S.P. Bio-Implant Interface: Improving Biomaterials and Tissue Reactions; CRC Press: London, UK, 2003.

5. Kasemo, B.; Lausmaa, J. Biomaterial and implant surfaces: A surface science approach. Int. J. Oral Maxillofac. Implants 1988, 3, 247-259. [PubMed]

6. Kasemo, B.; Lausmaa, J. Biomaterial and implant surfaces: On the role of cleanliness, contamination, and preparation procedures. J. Biomed. Mater. Res. 1988, 22, 145-158. [CrossRef] [PubMed]

7. Kasemo, B.; Lausmaa, J. Material-tissue interfaces: The role of surface properties and processes. Environ. Health Perspect. 1994, 102, 41-45. [PubMed]

8. Larsson Wexell, C.; Thomsen, P.; Aronsson, B.O.; Tengvall, P.; Rodahl, M.; Lausmaa, J.; Kasemo, B.; Ericson, L.E. Bone response to surface-modified titanium implants: Studies on the early tissue response to implants with different surface characteristics. Int. J. Biomater. 2013, 2013, 412482. [CrossRef] [PubMed]

9. Thomsen, P.; Larsson, C.; Ericson, L.E.; Sennerby, L.; Lausmaa, J.; Kasemo, B. Structure of the interface between rabbit cortical bone and implants of gold, zirconium and titanium. J. Mater. Sci. Mater. Med. 1997, 8 , 653-665. [CrossRef] [PubMed]

10. Rupp, F.; Gittens, R.A.; Scheideler, L.; Marmur, A.; Boyan, B.D.; Schwartz, Z.; Geis-Gerstorfer, J. A review on the wettability of dental implant surfaces i: Theoretical and experimental aspects. Acta Biomater. 2014, 10, 2894-2906. [CrossRef] [PubMed]

11. Rupp, F.; Scheideler, L.; Olshanska, N.; de Wild, M.; Wieland, M.; Geis-Gerstorfer, J. Enhancing surface free energy and hydrophilicity through chemical modification of microstructured titanium implant surfaces. J. Biomed. Mater. Res. A 2006, 76, 323-334. [CrossRef] 
12. Wennerberg, A.; Albrektsson, T. On implant surfaces: A review of current knowledge and opinions. Int. J. Oral Maxillofac. Implants 2010, 25, 63-74.

13. Rupp, F.; Liang, L.; Geis-Gerstorfer, J.; Scheideler, L.; Huttig, F. Surface characteristics of dental implants: A review. Dent. Mater. 2018, 34, 40-57. [CrossRef]

14. Rodriguez y Baena, R.; Rizzo, S.; Manzo, L.; Lupi, S.M. Nanofeatured titanium surfaces for dental implantology: Biological effects, biocompatibility, and safety. J. Nanomater. 2017. [CrossRef]

15. Nishimura, I. Genetic networks in osseointegration. J. Dent. Res. 2013, 92, 109S-118S. [CrossRef] [PubMed]

16. Smeets, R.; Stadlinger, B.; Schwarz, F.; Beck-Broichsitter, B.; Jung, O.; Precht, C.; Kloss, F.; Grobe, A.; Heiland, M.; Ebker, T. Impact of dental implant surface modifications on osseointegration. Biomed. Res. Int. 2016, 2016, 6285620. [CrossRef] [PubMed]

17. Brett, E.; Flacco, J.; Blackshear, C.; Longaker, M.T.; Wan, D.C. Biomimetics of bone implants: The regenerative road. Biores. Open Access 2017, 6, 1-6. [CrossRef] [PubMed]

18. Insua, A.; Monje, A.; Wang, H.L.; Miron, R.J. Basis of bone metabolism around dental implants during osseointegration and peri-implant bone loss. J. Biomed. Mater. Res. A 2017, 105, 2075-2089. [CrossRef] [PubMed]

19. Bryers, J.D.; Giachelli, C.M.; Ratner, B.D. Engineering biomaterials to integrate and heal: The biocompatibility paradigm shifts. Biotechnol. Bioeng. 2012, 109, 1898-1911. [CrossRef]

20. Morra, M. Biochemical modification of titanium surfaces: Peptides and ecm proteins. Eur. Cell. Mater. 2006, 12, 1-15. [CrossRef]

21. Morra, M. Biomolecular modification of implant surfaces. Expert Rev. Med. Devices 2007, 4, 361-372. [CrossRef]

22. Puleo, D.A.; Nanci, A. Understanding and controlling the bone-implant interface. Biomaterials 1999, 20, 2311-2321. [CrossRef]

23. Morra, M.; Cassinelli, C.; Cascardo, G.; Cahalan, P.; Cahalan, L.; Fini, M.; Giardino, R. Surface engineering of titanium by collagen immobilization. Surface characterization and in vitro and in vivo studies. Biomaterials 2003, 24, 4639-4654. [CrossRef]

24. Morra, M.; Cassinelli, C.; Cascardo, G.; Mazzucco, L.; Borzini, P.; Fini, M.; Giavaresi, G.; Giardino, R. Collagen i-coated titanium surfaces: Mesenchymal cell adhesion and in vivo evaluation in trabecular bone implants. J. Biomed. Mater. Res. A 2006, 78, 449-458. [CrossRef] [PubMed]

25. Morra, M.; Cassinelli, C.; Cascardo, G.; Nagel, M.D.; Della Volpe, C.; Siboni, S.; Maniglio, D.; Brugnara, M.; Ceccone, G.; Schols, H.A.; et al. Effects on interfacial properties and cell adhesion of surface modification by pectic hairy regions. Biomacromolecules 2004, 5, 2094-2104. [CrossRef] [PubMed]

26. Kim, H.W.; Li, L.H.; Lee, E.J.; Lee, S.H.; Kim, H.E. Fibrillar assembly and stability of collagen coating on titanium for improved osteoblast responses. J. Biomed. Mater. Res. A 2005, 75, 629-638. [CrossRef] [PubMed]

27. Rammelt, S.; Heck, C.; Bernhardt, R.; Bierbaum, S.; Scharnweber, D.; Goebbels, J.; Ziegler, J.; Biewener, A.; Zwipp, H. In vivo effects of coating loaded and unloaded ti implants with collagen, chondroitin sulfate, and hydroxyapatite in the sheep tibia. J. Orthop. Res. 2007, 25, 1052-1061. [CrossRef] [PubMed]

28. Rammelt, S.; Illert, T.; Bierbaum, S.; Scharnweber, D.; Zwipp, H.; Schneiders, W. Coating of titanium implants with collagen, rgd peptide and chondroitin sulfate. Biomaterials 2006, 27, 5561-5571. [CrossRef] [PubMed]

29. Stadlinger, B.; Pilling, E.; Huhle, M.; Mai, R.; Bierbaum, S.; Bernhardt, R.; Scharnweber, D.; Kuhlisch, E.; Hempel, U.; Eckelt, U. Influence of extracellular matrix coatings on implant stability and osseointegration: An animal study. J. Biomed. Mater. Res. B Appl. Biomater. 2007, 83, 222-231. [CrossRef] [PubMed]

30. Stadlinger, B.; Pilling, E.; Mai, R.; Bierbaum, S.; Berhardt, R.; Scharnweber, D.; Eckelt, U. Effect of biological implant surface coatings on bone formation, applying collagen, proteoglycans, glycosaminoglycans and growth factors. J. Mater. Sci. Mater. Med. 2008, 19, 1043-1049. [CrossRef] [PubMed]

31. Stadlinger, B.; Pilling, E.; Huhle, M.; Mai, R.; Bierbaum, S.; Scharnweber, D.; Kuhlisch, E.; Loukota, R.; Eckelt, U. Evaluation of osseointegration of dental implants coated with collagen, chondroitin sulphate and bmp-4: An animal study. Int. J. Oral Maxillofac. Surg. 2008, 37, 54-59. [CrossRef]

32. Kokkonen, H.; Verhoef, R.; Kauppinen, K.; Muhonen, V.; Jorgensen, B.; Damager, I.; Schols, H.A.; Morra, M.; Ulvskov, P.; Tuukkanen, J. Affecting osteoblastic responses with in vivo engineered potato pectin fragments. J. Biomed. Mater. Res. A 2012, 100, 111-119. [CrossRef] 
33. Gurzawska, K.; Svava, R.; Jorgensen, N.R.; Gotfredsen, K. Nanocoating of titanium implant surfaces with organic molecules. Polysaccharides including glycosaminoglycans. J. Biomed. Nanotechnol. 2012, 8, 1012-1024. [CrossRef]

34. Gurzawska, K.; Svava, R.; Syberg, S.; Yihua, Y.; Haugshoj, K.B.; Damager, I.; Ulvskov, P.; Christensen, L.H.; Gotfredsen, K.; Jorgensen, N.R. Effect of nanocoating with rhamnogalacturonan-i on surface properties and osteoblasts response. J. Biomed. Mater. Res. A 2012, 100, 654-664. [CrossRef] [PubMed]

35. Kellesarian, S.; Malignaggi, V.; Kellesarian, T.; Bashir Ahmed, H.; Javed, F. Does incorporating collagen and chondroitin sulfate matrix in implant surfaces enhance osseointegration? A systematic review and meta-analysis. IJOMS 2018, 47, 241-251. [CrossRef] [PubMed]

36. Evered, D.E.; Whelan, J.E. The Biology of Hyaluronan; Wiley: Chichester, UK, 1989.

37. Laurent, T.C. The Chemistry, Biology and Medical Applications of Hyaluronan and Its Derivative; Portland Press: London, UK, 1998.

38. Abatangelo, G.; Weigel, P.H. New Frontiers in Medical Sciences: Redefining Hyaluronan. In Proceedings of the Symposium on New Frontiers in Medical Sciences, Padua, Italy, 17-19 June 1999; Elsevier: Oxford, UK, 2000.

39. Kennedy, J.F.; Balazs, E.A.F.; Phillips, G.O.E.; Williams, P.A.E. Hyaluronan 2000: An International Meeting Celebrating the 80th Birthday of Endre a Balazs; Woodhead: Cambridge, CA, USA, 2002.

40. Morra, M. Engineering of biomaterials surfaces by hyaluronan. Biomacromolecules 2005, 6, 1205-1223. [CrossRef] [PubMed]

41. Valachova, K.; Volpi, N.; Stern, R.; Soltes, L. Hyaluronan in medical practice. Curr. Med. Chem. 2016, 23, 3607-3617. [CrossRef] [PubMed]

42. Salwowska, N.M.; Bebenek, K.A.; Zadlo, D.A.; Wcislo-Dziadecka, D.L. Physiochemical properties and application of hyaluronic acid: A systematic review. J. Cosmet. Dermatol. 2016, 15, 520-526. [CrossRef] [PubMed]

43. Casale, M.; Moffa, A.; Vella, P.; Sabatino, L.; Capuano, F.; Salvinelli, B.; Lopez, M.A.; Carinci, F.; Salvinelli, F. Hyaluronic acid: Perspectives in dentistry. A systematic review. Int. J. Immunopathol. Pharmacol. 2016, 29, 572-582. [CrossRef] [PubMed]

44. Maurer, P.H.; Hudack, S.S. The isolation of hyaluronic acid from callus tissue of early healing. Arch. Biochem. Biophys. 1952, 38, 49-53. [CrossRef]

45. Iwata, H.; Urist, M.R. Hyaluronic acid production and removal during bone morphogenesis in implants of bone matrix in rats. Clin. Orthop. Relat. Res. 1973, 236-245.

46. Bernard, G.W.; Pilloni, A.; Kang, M.; Sison, J.; Hunt, D.; Jovanovic, S. Osteogenesis in vitro and in vivo with hyaluronan and bone morphogenetic protein-2. In New Frontiers in Medical Sciences: Redefining Hyaluronan; Abatangelo, G., Weigel, P.H., Eds.; Elsevier: New York, NY, USA, 2000; pp. 215-231.

47. Zou, X.; Li, H.; Chen, L.; Baatrup, A.; Bunger, C.; Lind, M. Stimulation of porcine bone marrow stromal cells by hyaluronan, dexamethasone and rhbmp-2. Biomaterials 2004, 25, 5375-5385. [CrossRef]

48. Itoh, S.; Matubara, M.; Kawauchi, T.; Nakamura, H.; Yukitake, S.; Ichinose, S.; Shinomiya, K. Enhancement of bone ingrowth in a titanium fiber mesh implant by rhbmp-2 and hyaluronic acid. J. Mater. Sci. Mater. Med. 2001, 12, 575-581. [CrossRef]

49. Cho, B.C.; Park, J.W.; Baik, B.S.; Kwon, I.C.; Kim, I.S. The role of hyaluronic acid, chitosan, and calcium sulfate and their combined effect on early bony consolidation in distraction osteogenesis of a canine model. J. Craniofac. Surg. 2002, 13, 783-793. [CrossRef] [PubMed]

50. Solchaga, L.A.; Temenoff, J.S.; Gao, J.; Mikos, A.G.; Caplan, A.I.; Goldberg, V.M. Repair of osteochondral defects with hyaluronan- and polyester-based scaffolds. Osteoarthr. Cartilage 2005, 13, 297-309. [CrossRef]

51. Zhao, N.; Wang, X.; Qin, L.; Guo, Z.; Li, D. Effect of molecular weight and concentration of hyaluronan on cell proliferation and osteogenic differentiation in vitro. Biochem. Biophys. Res. Commun. 2015, 465, 569-574. [CrossRef] [PubMed]

52. Aebli, N.; Stich, H.; Schawalder, P.; Theis, J.C.; Krebs, J. Effects of bone morphogenetic protein-2 and hyaluronic acid on the osseointegration of hydroxyapatite-coated implants: An experimental study in sheep. J. Biomed. Mater. Res. A 2005, 73, 295-302. [CrossRef] [PubMed]

53. Morra, M.; Cassinelli, C.; Cascardo, G.; Fini, M.; Giavaresi, G.; Giardino, R. Covalently-linked hyaluronan promotes bone formation around ti implants in a rabbit model. J. Orthop. Res. 2009, 27, 657-663. [CrossRef] 
54. Gomi, K.; Davies, J.E. Guided bone tissue elaboration by osteogenic cells in vitro. J. Biomed. Mater. Res. 1993, 27, 429-431. [CrossRef] [PubMed]

55. Lossdorfer, S.; Schwartz, Z.; Wang, L.; Lohmann, C.H.; Turner, J.D.; Wieland, M.; Cochran, D.L.; Boyan, B.D. Microrough implant surface topographies increase osteogenesis by reducing osteoclast formation and activity. J. Biomed. Mater. Res. A 2004, 70, 361-369. [CrossRef]

56. Morra, M.; Cassinelli, C.; Bruzzone, G.; Carpi, A.; Di Santi, G.; Giardino, R.; Fini, M. Surface chemistry effects of topographic modification of titanium dental implant surfaces: 1. Surface analysis. Int. J. Oral Maxillofac. Implants 2003, 18, 40-45.

57. Morra, M.; Cassinelli, C. Simple model for the xps analysis of polysaccharides coated surface. Surf. Interface Anal. 1998, 26, 742-747. [CrossRef]

58. Briggs, D.; Seah, M.P. Practical surface analysis. In Auger and X-ray Photoelectron Spectroscopy; Wiley: Chichester, UK, 1996.

59. Shard, A.; Davies, M.; Tendler, S.; Bennedetti, L.; Purbrick, M.; Paul, A.; Beamson, G. X-ray photoelectron spectroscopy and time-of-flight sims investigations of hyaluronic acid derivatives. Langmuir 1997, 13, 2808-2814. [CrossRef]

60. Goldstein, J. Scanning Electron Microscopy and X-ray Microanalysis; Plenum Press: New York, NY, USA, 2003.

61. Lausmaa, J. Surface spectroscopic characterization of titanium implant materials. J. Electron. Spectros. Relat. Phenomena 1996, 81, 343-361. [CrossRef]

62. Sawase, T.; Hai, K.; Yoshida, K.; Baba, K.; Hatada, R.; Atsuta, M. Spectroscopic studies of three osseointegrated implants. J. Dent. 1998, 26, 119-124. [CrossRef]

63. Kang, B.S.; Sul, Y.T.; Oh, S.J.; Lee, H.J.; Albrektsson, T. Xps, aes and sem analysis of recent dental implants. Acta Biomater. 2009, 5, 2222-2229. [CrossRef] [PubMed]

64. Cassinelli, C.; Morra, M.; Pavesio, A.; Renier, D. Evaluation of interfacial properties of hyaluronan coated poly(methylmethacrylate) intraocular lenses. J. Biomater. Sci. Polym. Ed. 2000, 11, 961-977. [CrossRef]

65. Sverzut, A.T.; Crippa, G.E.; Morra, M.; de Oliveira, P.T.; Beloti, M.M.; Rosa, A.L. Effects of type i collagen coating on titanium osseointegration: Histomorphometric, cellular and molecular analyses. Biomed. Mater. 2012, 7, 035007. [CrossRef] [PubMed]

66. Sartori, M.; Giavaresi, G.; Parrilli, A.; Ferrari, A.; Aldini, N.N.; Morra, M.; Cassinelli, C.; Bollati, D.; Fini, M. Collagen type i coating stimulates bone regeneration and osteointegration of titanium implants in the osteopenic rat. Int. Orthop. 2015, 39, 2041-2052. [CrossRef]

67. Litwiniuk, M.; Krejner, A.; Speyrer, M.S.; Gauto, A.R.; Grzela, T. Hyaluronic acid in inflammation and tissue regeneration. Wounds 2016, 28, 78-88.

68. Maytin, E.V. Hyaluronan: More than just a wrinkle filler. Glycobiology 2016, 26, 553-559. [CrossRef]

69. Zhao, N.; Wang, X.; Qin, L.; Zhai, M.; Yuan, J.; Chen, J.; Li, D. Effect of hyaluronic acid in bone formation and its applications in dentistry. J. Biomed. Mater. Res. A 2016, 104, 1560-1569. [CrossRef]

70. Gurgel, B.C.V.; Montenegro, S.C.L.; Dantas, P.M.C.; Pascoal, A.L.B.; Lima, K.C.; Calderon, P.D.S. Frequency of peri-implant diseases and associated factors. Clin. Oral Implants Res. 2017, 28, 1211-1217. [CrossRef]

71. Morra, M.; Cassineli, C. Non-fouling properties of polysaccharide-coated surfaces. J. Biomater. Sci. Polym. Ed. 1999, 10, 1107-1124. [CrossRef] [PubMed]

72. Davies, J.E. Bone Engineering; University of Toronto Press: Toronto, ON, Canada, 2000.

73. Rizzo, S.; Zampetti, P.; Rodriguez, Y.B.R.; Svanosio, D.; Lupi, S.M. Retrospective analysis of 521 endosseous implants placed under antibiotic prophylaxis and review of literature. Minerva. Stomatol. 2010, 59, 75-88. [PubMed]

74. Lupi, S.M.; Rodriguez, Y.B.A.; Cervino, G.; Todaro, C.; Rizzo, S. Long-term effects of acute myeloid leukemia treatment on the oral system in a pediatric patient. Open Dent. J. 2018, 12, 230-237. [CrossRef] [PubMed]

75. Rodriguez y Baena, R.; Pastorino, R.; Gherlone, E.F.; Perillo, L.; Lupi, S.M.; Lucchese, A. Histomorphometric evaluation of two different bone substitutes in sinus augmentation procedures: A randomized controlled trial in humans. Int. J. Oral Maxillofac. Implants 2017, 32, 188-194. [CrossRef] [PubMed]

76. Lupi, S.M.; Cislaghi, M.; Rizzo, S.; Rodriguez, Y.B.R. Rehabilitation with implant-retained removable dentures and its effects on perioral aesthetics: A prospective cohort study. Clin. Cosmet. Investig. Dent. 2016, 8, 105-110. [PubMed] 
77. RR, Y.B.; Lupi, S.M.; Pastorino, R.; Maiorana, C.; Lucchese, A.; Rizzo, S. Radiographic evaluation of regenerated bone following poly(lactic-co-glycolic) acid/hydroxyapatite and deproteinized bovine bone graft in sinus lifting. J. Craniofac. Surg. 2013, 24, 845-848.

78. Rodriguez, Y.B.R.; D'Aquino, R.; Graziano, A.; Trovato, L.; Aloise, A.C.; Ceccarelli, G.; Cusella, G.; Pelegrine, A.A.; Lupi, S.M. Autologous periosteum-derived micrografts and plga/ha enhance the bone formation in sinus lift augmentation. Front. Cell Dev. Biol. 2017, 5, 87. [CrossRef] [PubMed]

79. Ceccarelli, G.; Presta, R.; Lupi, S.M.; Giarratana, N.; Bloise, N.; Benedetti, L.; Cusella De Angelis, M.G.; Rodriguez, Y.B.R. Evaluation of poly(lactic-co-glycolic) acid alone or in combination with hydroxyapatite on human-periosteal cells bone differentiation and in sinus lift treatment. Molecules 2017, 22. [CrossRef] [PubMed]

80. Lupi, S.M.; Rodriguez, Y.B.A.; Todaro, C.; Ceccarelli, G.; Rodriguez, Y.B.R. Maxillary sinus lift using autologous periosteal micrografts: A new regenerative approach and a case report of a 3-year follow-up. Case Rep. Dent. 2018, 2018, 3023096. [CrossRef]

81. Lupi, S.M.; Granati, M.; Butera, A.; Collesano, V.; Rodriguez, Y.B.R. Air-abrasive debridement with glycine powder versus manual debridement and chlorhexidine administration for the maintenance of peri-implant health status: A six-month randomized clinical trial. Int. J. Dent. Hyg. 2017, 15, 287-294. [CrossRef]

82. Mumcu, E.; Bilhan, H.; Cekici, A. Marginal bone loss around implants supporting fixed restorations. J. Oral Implantol. 2011, 37, 549-558. [CrossRef] [PubMed]

83. Julious, S.A. Sample sizes for clinical trials with normal data. Stat. Med. 2004, 23, 1921-1986. [CrossRef] [PubMed]

(C) 2019 by the authors. Licensee MDPI, Basel, Switzerland. This article is an open access article distributed under the terms and conditions of the Creative Commons Attribution (CC BY) license (http://creativecommons.org/licenses/by/4.0/). 